\title{
Possible effects of pollock and herring on the growth and reproductive success of Steller sea lions (Eumetopias jubatus): insights from feeding experiments using an alternative animal model, Rattus norvegicus
}

\author{
Carolyn P. Donnelly ${ }^{1}$, A. W. Trites ${ }^{1 *}$ and D. D. Kitts ${ }^{2}$ \\ ${ }^{1}$ Marine Mammal Research Unit, The University of British Columbia, Room 18, Hut B-3, 6248 Biological Sciences Road, \\ Vancouver, British Columbia, V6T 1Z4, Canada \\ ${ }^{2}$ Food Nutrition and Health, The University of British Columbia, 6650 NW Marine Drive, Vancouver, British Columbia, \\ V6T 1Z4, Canada
}

(Received 17 July 2001 - Revised 6 August 2002 - Accepted 6 September 2002)

\begin{abstract}
The decline of Steller sea lions (Eumetopias jubatus) in the Gulf of Alaska appears to have been associated with a switch of diet from one dominated by fatty forage fishes (such as herring; Clupea pallasi) to one dominated by low-fat fish (such as pollock; Theragra chalcogramma). Observations made during the decline include reduced body size of sea lions, low pregnancy rates, and high mortality. We used the general mammalian model, the laboratory rat (Rattus norvegicus), to test whether changing the quality of prey consumed could cause changes in size and reproductive performance. Five groups of twelve female, weanling rats were fed diets composed of herring $(\mathrm{H})$, pollock $(\mathrm{P})$, pollock supplemented with herring oil $(\mathrm{PH})$, pollock supplemented with pollock oil (PP), or a semi-purified diet (ICN). Mean body weights were greatest for $\mathrm{H}$, followed by $\mathrm{PH}, \mathrm{P}, \mathrm{PP}$ and finally ICN, although ICN was the only group significantly different from the others $(P<0 \cdot 05)$. Food intakes before mating were $10 \%$ higher for groups on the lower-fat diets $(\mathrm{P}$ and $\mathrm{ICN})$, resulting in similar energy intakes in all groups. The protein efficiency ratio was highest for the $\mathrm{H}$ diet, slightly lower for all pollock diets, and significantly lower for ICN $(P<0.05)$. The fetal weights for mothers fed $\mathrm{P}$ were significantly reduced $(P<0.05)$. The present study shows that the energy content was a major limiting factor in the nutritional quality of pollock. When food intake was adjusted to meet energetic requirements, there were no detrimental consequences from eating pollock. However, supplementation of pollock meal with additional pollock oil may reduce growth and reproductive performance, although the reasons for this were not apparent.
\end{abstract}

Steller sea lions: Growth: Reproduction: Energy requirements

Steller sea lion (Eumetopias jubatus) populations in the Gulf of Alaska and the Aleutian Islands have declined by over $85 \%$ since the late 1970 s in parallel with an apparent ecosystem shift in the composition of fish; most notably an increase in gadids such as walleye pollock (Theragra chalcogramma) and a decrease in Pacific herring (Clupea pallasi ) (Alverson, 1992; Alaska Sea Grant, 1993; Trites \& Larkin, 1996; Calkins et al. 1999; Trites et al. 1999; Benson \& Trites, 2002). Stomach contents of Steller sea lions reflect this change in availability with a shift in dominant prey species from herring to pollock (Pitcher, 1981; Merrick \& Calkins, 1996). From a physiological context, these dietary changes have been accompanied by reduced body size (length and mass) and reduced pup numbers
(Calkins et al. 1998). One hypothesis linking the above observations is that the sea lions experienced a nutritional deficiency when their dominant prey species shifted from a fatty fish (for example, herring) to a non-fatty fish (for example, pollock) (Alverson, 1992).

Studies using captive juvenile Steller sea lions have found them unable to maintain body mass on diets of pollock, while sea lions gained weight when fed herring (Rosen \& Trites, 2000b). Studies of mink have found them also unable to maintain body mass while consuming gadids, even when their intake increased significantly (Leoschke, 1961). Unfortunately, captive studies of Steller sea lions are limited by small sample sizes and are unable to examine the subtle effects of diet on reproduction due to 
their lengthy reproductive cycle. These shortcomings make it necessary to examine alternative animal models in Steller sea lion research.

The purpose of our study was to examine the nutritional value of pollock and herring using the laboratory rat (Rattus norvegicus), a common model for nutritional studies in mammals, and one that is increasingly being used in studies of marine mammals (Ross et al. 1996, 1997).

Our study compared the nutritional value of pollock and herring by monitoring diet-induced changes in growth, food intake and utilization efficiencies of rats fed different fish diets. We also examined the effect of pollock and herring diets on reproductive parameters such as gestational weight gain, litter sizes and litter weights. We hypothesized that a deficiency in energy or nutrient intake associated with eating pollock would lead to inefficiencies in body growth and reproduction of rats or sea lions that would negatively affect their population dynamics.

\section{Methods}

\section{Diet preparation}

Herring and pollock were caught off the coast of Alaska and British Columbia (At Sea Processors and Vancouver Aquarium Marine Science Center) and frozen at $-30^{\circ} \mathrm{C}$. Within 1 week of arrival, all fish were ground while frozen using a Hobart meat grinder and immediately vacuum-packed in $4 \mathrm{ml}$ thick polyethylene bags before being stored at $-30^{\circ} \mathrm{C}$ in opaque boxes to prevent lipid oxidation. The ground fish was freeze-dried (Pleasant Valley Freeze Dry) and mixed into one of four experimental diets. Freshly mixed diets were immediately divided into $1 \mathrm{~kg}$ bags (approximately 3 days worth of feed), vacuum-packed and stored in opaque boxes at $-30^{\circ} \mathrm{C}$ until use. Once opened for use in experimental feeding, the diets were stored in airtight plastic containers at $5^{\circ} \mathrm{C}$ for a maximum of $3 \mathrm{~d}$. Peroxide values of the diets were taken on the first day of use and after $2 \mathrm{~d}$ of refrigeration (AOAC Official Method 965.33, 2000) and did not exceed 2 mequiv/kg fat.

Ten fish of each species were analysed for protein, fat, ash, fibre and moisture content as well as energy content to ensure that all of the diets fed to our study animals were balanced (Norwest Labs, Vancouver) (Table 1). Diets were formulated using ICN (Aurora, Ohio) semipurified diet components, the freeze-dried pollock and herring, and pollock and herring oil (At Sea Processors and West Coast Reduction) (Table 2). Diets contained

Table 1. Proximate composition ( $\mathrm{g} / \mathrm{kg} \mathrm{DM})$ analyses and energy content of fish used in experimental diets

(Mean values for ten independent samples)

\begin{tabular}{lcrrrc}
\hline & Protein & Fat & Fibre & Ash & Gross energy $(\mathrm{kJ} / \mathrm{g})$ \\
\hline Pollock & 645.7 & 255.5 & 19.6 & 113.9 & 26.12 \\
Herring & 542.8 & 438.4 & 7.8 & 87.0 & 30.50 \\
\hline
\end{tabular}

exact proportions of all ingredients of ICN's semi-purified AIN-76 powdered rat diet, less the protein and fat components. Protein (held constant at $20 \%$ ) and fat were provided through the freeze-dried fish and through added fish oil in two diets. The first diet contained pollock $(\mathrm{P})$ as the protein source and the second diet contained herring $(\mathrm{H})$, with fat values being those naturally occurring in these particular fish. The third diet contained pollock supplemented with pollock oil (PP), and the fourth diet was pollock supplemented with herring oil (PH). These supplemented diets both contained the same concentration of fat as the herring diet, and were therefore isoenergetic to the herring diet and effectively created 'fatty pollock'. The difference between these two diets was the source of the fish oil (for example, from pollock or herring) therefore enabling a comparison of the two fish oils. The fifth diet was a control diet (ICN), being the semi-purified AIN-76 rat diet, and was isoenergetic with the pollock diet. This diet was designed to ensure that responses obtained from the pollock group were due to the ingestion of fish, and not the result of energy intake (due to the low fat content of pollock $v$. herring). Energy and protein contents of all diets (Table 2) were confirmed before experimental feeding to ensure that: (1) diets P and ICN were isoenergetic; (2) diets $\mathrm{H}$, $\mathrm{PP}$ and $\mathrm{PH}$ were isoenergetic; (3) all diets contained equal proportions of protein.

Fatty acid profiles for all diets were determined in duplicate by GC. Lipids were extracted from diet samples with chloroform-methanol $(2: 1, \mathrm{v} / \mathrm{v})$ by the method described by Folch et al. (1957), methylated with $\mathrm{H}_{2} \mathrm{SO}_{4}$ and $\mathrm{CH}_{3} \mathrm{OH}$, and analysed for component fatty acids using a Shimadzu 3700 GC according to the method of Nwokolo \& Kitts (1988).

Fatty acid standards were ordered from Sigma, Inc. The fatty acid standard mixture included methyl esters of the following fatty acids: $12: 0,14: 0,16: 0,16: 1 n-9,17: 0$, $18: 0,18: 1 n-9,18: 2 n-6,18: 3 n-3,20: 4 n-6,20: 5 n-3$, $22: 6 n-3$

Amino acid profiles were also obtained for all diets (method JAOAC vol. 71, no. 6, 1988 by SGS Laboratories, Vancouver).

\section{Animal protocols}

A total of sixty weanling (approximately $22 \mathrm{~d}$ old) female Wistar rats (University of British Columbia breeding colony) were randomly divided into five groups (twelve per group) and assigned to one of the above five diets (Table 2). Rats were acclimatized to the laboratory and physical handling for $3 \mathrm{~d}$ before data collection. The animals were housed in stainless steel cages in a room with ambient temperature set at $21 \pm 1^{\circ} \mathrm{C}$, with ten air changes/ $\mathrm{h}$ and controlled lighting conditions ( $12 \mathrm{~h}$ light$12 \mathrm{~h}$ dark cycles). All procedures were in accordance with the University of British Columbia's Committee on Animal Care. Food and water were made available ad libitum until 9.00 hours each day, with the exception of the ICN group that was meal-fed with the $\mathrm{P}$ group. Fresh food was provided each morning after all measurements were taken. Portion dishes were washed daily, and uneaten food was weighed and discarded immediately. 
Table 2. Compositions ( $\mathrm{g} / \mathrm{kg}$ diet), gross energy and protein content $(\mathrm{g} / \mathrm{kg} \mathrm{diet)}$ of the five experimental diets

\begin{tabular}{|c|c|c|c|c|c|}
\hline & Herring & Pollock + herring oil & Pollock & Pollock + pollock oil & Control \\
\hline Fish protein & 200 & 200 & 200 & 200 & $0 \cdot 0^{*}$ \\
\hline DL-methionine & $3 \cdot 0$ & $3 \cdot 0$ & $3 \cdot 0$ & $3 \cdot 0$ & 3.0 \\
\hline Maize starch & 150 & 150 & 150 & 150 & 150 \\
\hline Sucrose & 381.5 & 358 & 440 & 358 & 500 \\
\hline Alflacel & 50 & 50 & 50 & 50 & 50 \\
\hline Natural oil† & $161 \cdot 6$ & 79 & 79 & 79 & 50 \\
\hline Mineral mix & 35 & 35 & 35 & 35 & 35 \\
\hline Vitamin mix & 10 & 10 & 10 & 10 & 10 \\
\hline Choline bitartrate & $2 \cdot 0$ & $2 \cdot 0$ & $2 \cdot 0$ & $2 \cdot 0$ & $2 \cdot 0$ \\
\hline Added oil & 0.0 & $82 \cdot 6$ & 0.0 & $8 \cdot 26$ & 0.0 \\
\hline Gross energy $(\mathrm{kJ} / \mathrm{g})$ & $20 \cdot 25^{b}$ & $20 \cdot 73^{b}$ & $18 \cdot 47^{\mathrm{a}}$ & $20 \cdot 89^{b}$ & $18 \cdot 73^{a}$ \\
\hline Protein content & $171 \cdot 3^{\mathrm{c}}$ & $183 \cdot 7^{c}$ & $170 \cdot 6^{c}$ & $187 \cdot 6^{\mathrm{c}}$ & $188 \cdot 3^{c}$ \\
\hline
\end{tabular}

${ }^{a, b, c}$ Values within a row with unlike superscript letters were significantly different $(P<0.05)$.

* The protein source in the control diet was casein $(20 \%)$.

† Oil content of fish in fish diets, and maize oil in the control diet.

\section{Growth parameters}

Body weights were recorded three times a week. Length (crown to rump) and girth (measured just anterior of the pelvic girdle) were recorded once a week.

Body condition index for each rat was calculated as: body condition index $=$ measured mass - expected mass from a repeated measures regression of mass on length (Fig. 1).

\section{Food intake}

Each morning, food spillage was retrieved from trays under the cages and added to each rat's leftover food. This was subtracted from the amount of food supplied the night before and recorded as food intake. On the rare occasion that water or urine had wet a rat's spilled food, food intake was not recorded for that day.

\section{Efficiency of energy utilization and protein efficiency ratio}

Efficiency of energy utilization was calculated as the

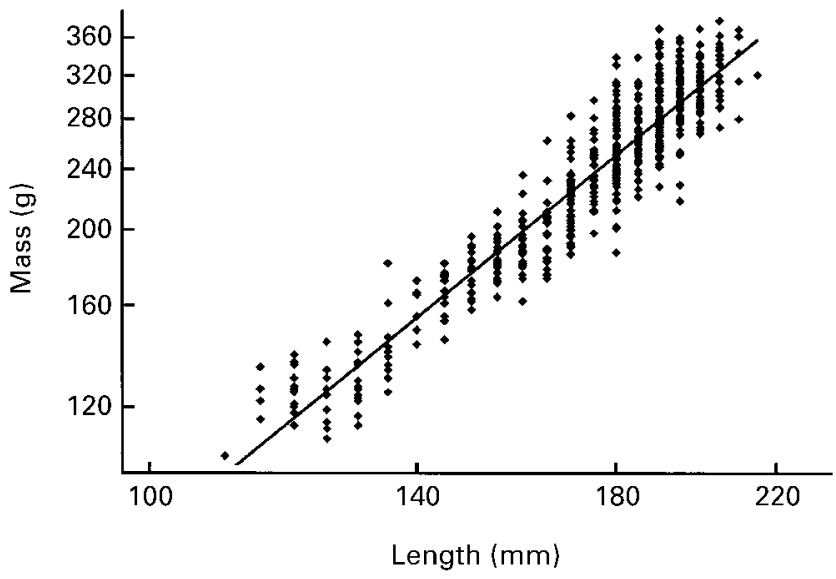

Fig. 1. The relationship between length and mass in Wistar rats used to calculate the body condition index (observed mass/ expected mass). Repeated-measures regression of the logtransformed data was $y=2.1538 x-0.7836$ ( $n$ 60, $r^{2} 0.9211$; $P<0.001)$. weight gain over 9 weeks, divided by the energy intake (Harris, 1991; Mehta et al. 1994; Iossa et al. 1997); protein efficiency ratio was calculated as the weight gain over 9 weeks divided by the amount of protein consumed (Muller \& Tobin, 1980).

\section{Reproductive parameters}

As the rats approached puberty (about $35 \mathrm{~d}$ old), they were examined daily for vaginal opening as evidence of first oestrus.

Starting at an age of approximately 13 weeks, rats were mated using a staggered, individual, overnight breeding schedule. The first morning on which copulatory plugs were observed or vaginal lavages showed sperm under a compound microscope was termed day 0 of gestation. On day 19 of gestation ( $2 \mathrm{~d}$ before parturition), rats were weighed and blood samples were obtained via heart puncture under halothane anaesthetic (Bimeda-MTC, Cambridge, $\mathrm{ON}$ ). Blood was collected in heparinized syringes, transferred to heparinized vacutainers, and put on ice. Within $1 \mathrm{~h}$, the plasma was separated by centrifugation at $4^{\circ} \mathrm{C}$ and then stored at $-30^{\circ} \mathrm{C}$ until analysed. Fetal and placental weights, the number of corpora lutea, total conceptus weights (fetuses within uterus), ovarian weights and litter size (number of fetuses/female) were recorded.

\section{Statistical analysis}

Differences between groups in all measured parameters were analysed by ANOVA or repeated-measures ANOVA unless otherwise stated. Differences were considered significant at $P \leq 0.05$ unless otherwise stated.

\section{Results}

\section{Diet analyses}

The fatty acid profiles of all five diets are shown in Table 3 . The polyunsaturated:saturated fatty acids ratio was highest for the ICN diet $(3 \cdot 30)$ and lowest for the $\mathrm{H}$ diet $(0 \cdot 38)$. 
Table 3. Fatty acid compositions ( $\mathrm{g} / 100 \mathrm{~g}$ fatty acids), polyunsaturated fatty acids (PUFA):saturated fatty acids (SFA) and $n-3: n-6$ ratios of treatment diets and oils used in the formulation of supplemented diets

(Mean values of duplicate analyses)

\begin{tabular}{|c|c|c|c|c|c|c|c|}
\hline & Pollock oil & Pollock & Pollock + pollock oil & Herring oil & Pollock + herring oil & Herring & Control \\
\hline \multicolumn{8}{|c|}{ Fatty acid composition } \\
\hline $10: 0$ & 0.21 & 0.48 & 0.28 & $0 \cdot 12$ & 0.24 & 0.23 & 0.17 \\
\hline $14: 0$ & 8.02 & 8.36 & 8.40 & 4.06 & 5.83 & $6 \cdot 68$ & 0.32 \\
\hline $16: 0$ & $22 \cdot 01$ & $25 \cdot 34$ & $23 \cdot 61$ & $25 \cdot 97$ & 24.29 & 31.65 & 12.55 \\
\hline $16: 1$ & $16 \cdot 47$ & $11 \cdot 77$ & 14.59 & $7 \cdot 21$ & $9 \cdot 39$ & $7 \cdot 18$ & 0.10 \\
\hline $18: 0$ & 3.78 & $5 \cdot 67$ & 4.57 & 4.90 & 4.46 & 4.38 & 3.09 \\
\hline $18: 1 n-9$ & $29 \cdot 27$ & 21.68 & $25 \cdot 51$ & $47 \cdot 43$ & 37.23 & 33.68 & 30.46 \\
\hline $18: 2 n-6$ & 1.25 & 1.28 & 1.39 & 0.98 & $1 \cdot 10$ & 1.56 & 52.49 \\
\hline $18: 3 n-3$ & 0.46 & 0.22 & 0.42 & 0.29 & 0.38 & 0.64 & 0.82 \\
\hline $20: 4 n-6$ & 0.51 & 0.38 & 0.45 & 0.17 & 0.26 & 0.30 & 0.00 \\
\hline $20: 5 n-3$ & $12 \cdot 21$ & 14.79 & $13 \cdot 28$ & $5 \cdot 31$ & $10 \cdot 01$ & 7.94 & 0.00 \\
\hline $22: 6 n-3$ & $5 \cdot 81$ & $10 \cdot 03$ & 7.50 & 3.56 & $6 \cdot 81$ & $5 \cdot 76$ & 0.00 \\
\hline Total & $100 \cdot 00$ & $100 \cdot 00$ & $100 \cdot 00$ & $100 \cdot 00$ & $100 \cdot 00$ & $100 \cdot 00$ & $100 \cdot 00$ \\
\hline PUFA:SFA & 0.56 & 0.67 & 0.62 & 0.29 & 0.53 & 0.38 & 3.30 \\
\hline$n-3: n-6$ & $10 \cdot 50$ & $15 \cdot 10$ & 11.50 & $7 \cdot 96$ & $12 \cdot 66$ & $7 \cdot 71$ & 0.01 \\
\hline
\end{tabular}

The $n-3: n-6$ ratio was highest for the $\mathrm{P} \operatorname{diet}(15 \cdot 10)$, intermediate for the $\mathrm{H}$ diet (7.71), and lowest for the ICN diet (0.01). As expected, fish diets were high in long-chain polyunsaturated fatty acids, with the $\mathrm{P}$ diet containing almost twice as much eicosapentaenoic acid (20:5n-3) and docosahexaenoic acid $(22: 6 n-3)$ as the $\mathrm{H}$ diet. The ICN diet containing maize oil was high in linoleic acid $(18: 2 n-6)$, but did not contain long-chain polyunsaturated fatty acids. Herring oil was highest in oleic acid (18:1n-9).

The amino acid profiles for all diets are shown in Table 4, along with the nutritional requirements of the rat (Warner \& Breuer, 1972). Intra-assay variation between replicate analyses on protein standards by SGS Laboratories was less than $2 \%$. The PH and PP diets contained slight deficiencies in isoleucine, and the PH diet was also slightly low in phenylalanine.

\section{Growth}

The growth curves for each diet group before mating are shown in Fig. 2. On day 60, rats fed the $\mathrm{H}, \mathrm{PH}$ and $\mathrm{P}$ diets were significantly larger than rats eating ICN $\left(F_{(4,55)}=3.52 ; P=0.002\right)$. The total weight gains from weaning to killing (day 19 of pregnancy) are shown in Fig. 3. ICN rats were significantly smaller than all rats fed fish diets $\left(F_{(4,44)}=6 \cdot 15 ; P<0 \cdot 001\right)$. Rats eating herring were heavier on average at all stages of development compared with those fed pollock (P, PP and PH), although the difference was not statistically significant for our given sample size.

Figure 1 shows the significant correlation between mass and length of rats before mating, and the repeatedmeasures linear regression $\left(r^{2} 0.92, n 60 ; P=0 \cdot 001\right)$ used to calculate the body condition index. Rats fed the $\mathrm{P}$ diet

Table 4. Amino acid profiles ( $\mathrm{g} / \mathrm{kg} \mathrm{DM})$ of treatment diets and requirements of the laboratory rat (Mean values of duplicate analyses)

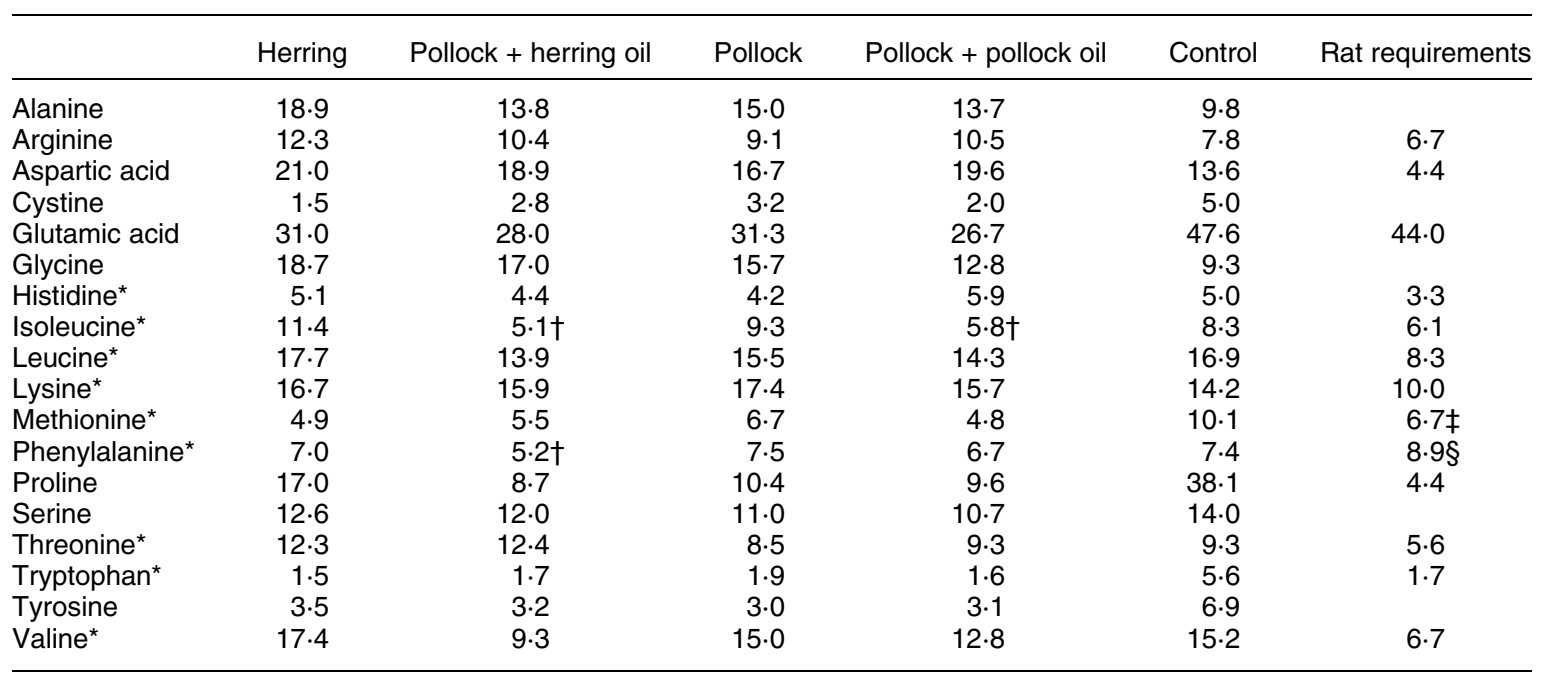

*Essential amino acid.

†Less than requirements according to Warner \& Breuer (1972).

$\ddagger$ One-third to a half may be supplied by L-cystine.

$\S$ Phenylalanine-tyrosine; one-third to a half may be supplied by L-tyrosine. 


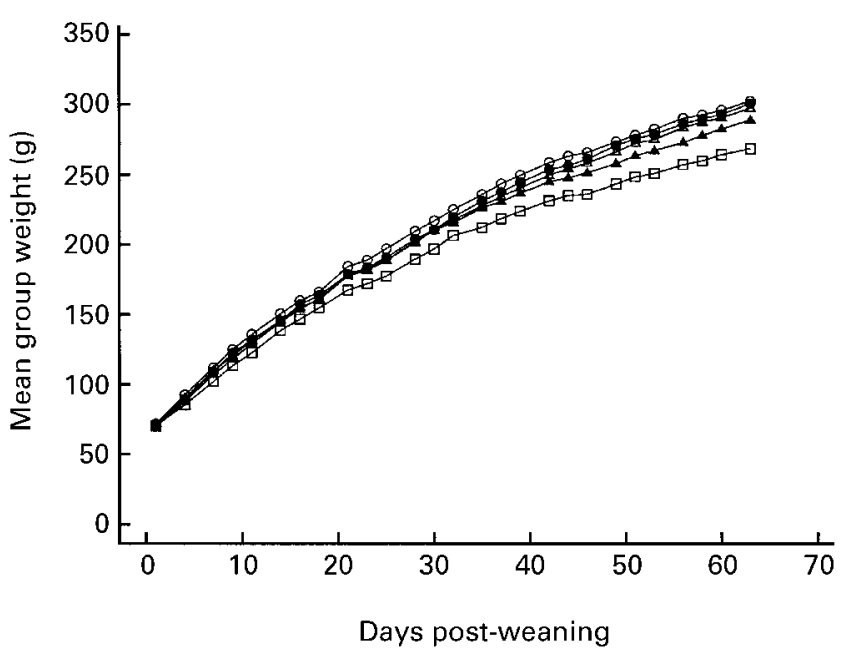

Fig. 2. Mean group body weights for rats fed different fish diets or a semi-purified control $(\square)$ diet. ( $\square$ ), Herring; $(\bullet)$, pollock + herring oil; $(\triangle)$, pollock; $(\boldsymbol{\Delta})$, pollock + pollock oil ( $n 12$ rats/diet). Control rats weighed significantly less than herring, pollock + herring oil and pollock rats on day $60(P=0.002)$.

had a significantly higher condition index than rats fed ICN diet throughout the first 9 weeks $\left(F_{(4,55)}=2.56 ; P=\right.$ 0.008 ), but there were no differences in condition between groups eating fish diets (Fig. 4).

\section{Food intake}

Mean food and energy intakes before mating are shown in Fig. 5. Food intakes for rats fed the lower-energy diets ( $P$ and ICN) were significantly higher than those fed the higher-energy diets $(\mathrm{H}, \mathrm{PH}$ and $\mathrm{PP})\left(F_{(4,55)}=17 \cdot 02\right.$; $P<0 \cdot 001)$. The differences in energy density of the diets was about $10 \%$ (Table 2), and intake was about $10 \%$ higher in the groups consuming the lower-energy diets

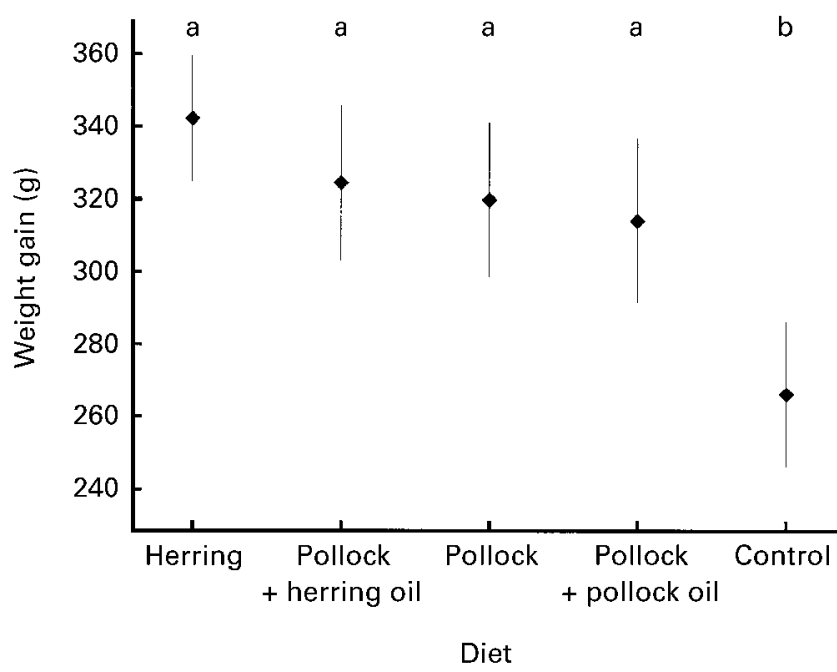

Fig. 3. Mean total weight gain (minus weight of conceptus) from weaning to day 19 of pregnancy with $95 \%$ confidence intervals represented by vertical bars. Rats were randomly mated, and age at day 19 of pregnancy ranged from 13-18 weeks. Mean values with unlike letters were significantly different $(P<0.001)$.

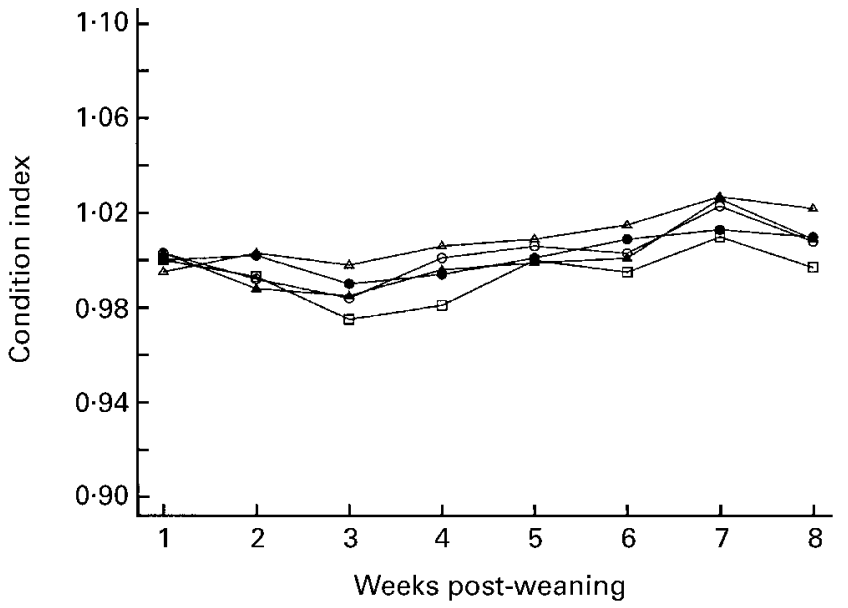

Fig. 4. Condition indices (observed mass/expected mass) of rats fed different fish diets or control diet $(\square)$ from weaning to 9 weeks post-weaning. ( $\square)$, Herring; $(\bullet)$, pollock + herring oil; $(\triangle)$, pollock; $(\mathbf{\Lambda})$, pollock + pollock oil ( $n 12$ rats/group).

(Fig. $5(\mathrm{~A}))$. Energy intake, therefore, was equal in all groups $($ Fig. $5(\mathrm{~B}))\left(F_{(4,55)}=2 \cdot 20 ; P=0 \cdot 08\right)$.

\section{Efficiency of energy utilization and protein efficiency ratio}

Energy utilization was highest for rats fed diet $\mathrm{P}(0 \cdot 018 \times$ $\left.10^{-5} \mathrm{~g} / \mathrm{kJ}\right)$, and significantly reduced for rats fed ICN
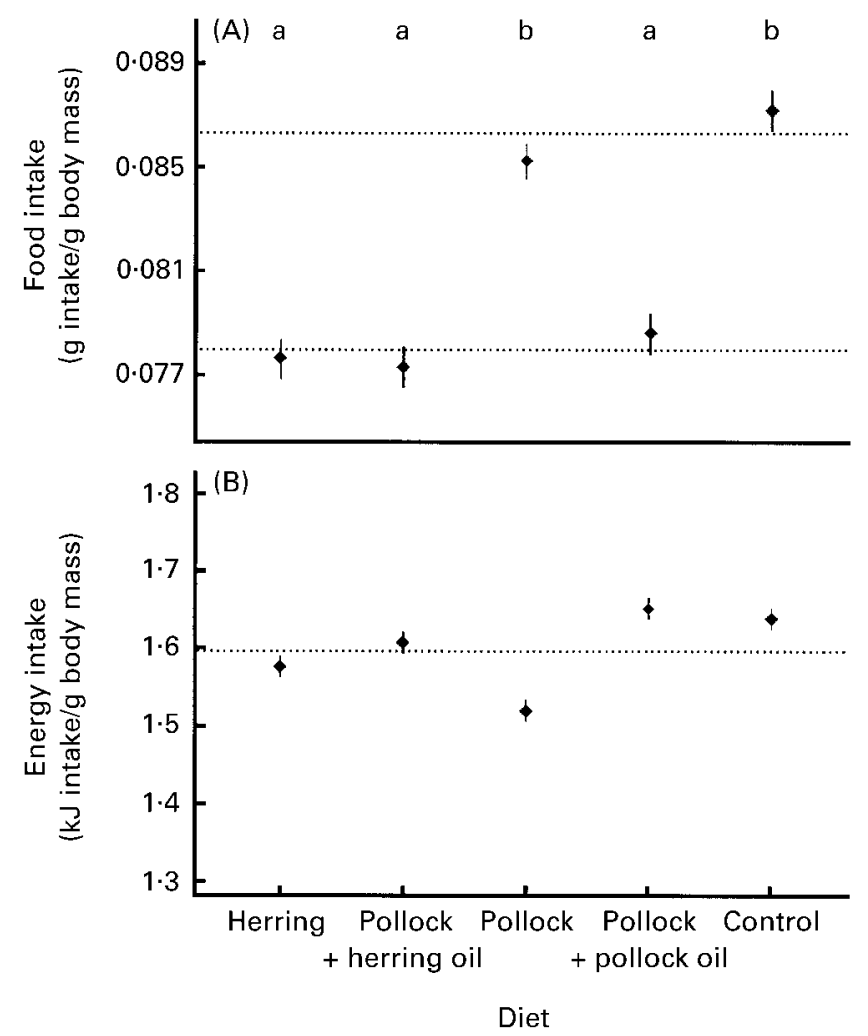

Fig. 5. Mean daily food (A) and energy intake (B) of non-pregnant rats fed different fish diets or control diet. Vertical bars are $95 \%$ confidence intervals ( $n 12$ rats/group). Mean values with unlike letters were significantly different $(P<0 \cdot 001)$. ( $\cdots)$, Means of statistically similar groups. 
$\left(0.016 \times 10^{-5} \mathrm{~g} / \mathrm{kJ}\right) \quad\left(F_{(4.55)}=2.97 ; \quad P=0.027\right) \quad($ Fig. 6 (A)). Adding both herring and pollock oil to the pollock diets slightly reduced this efficiency of energy utilization, although not significantly.

Protein efficiency ratio was highest for rats that were fed herring $(7.43)$ and lowest for ICN rats $(5 \cdot 81)\left(F_{(4,55)}=\right.$ 18.702; $P<0.001$; Fig. 6 (B)). Rats fed pollock, regardless of fat content, had protein efficiency values between $6 \cdot 8$ and $7 \cdot 0$.

\section{Reproduction}

Mass-corrected daily food intake during pregnancy ranged from $0.061 \mathrm{~g} / \mathrm{g}$ body mass to $0.066 \mathrm{~g} / \mathrm{g}$ body mass. There were no significant differences in food intake among dietary treatments (Table 5). Mass-corrected daily energy intake ranged from 1.20 to $1.29 \mathrm{~kJ} / \mathrm{g}$ body mass. Again, there were no significant differences in energy intakes observed. The mean energy intake for all rats during pregnancy was $439 \mathrm{~kJ} / \mathrm{d}$.

Mean litter size (13.5 fetuses) and gestational weight gain $(53.1 \mathrm{~g})$ did not differ significantly between all dietary groups (Fig. 7). Nor was there a difference in the interval from birth to first oestrus between groups, the mean age being $43 \mathrm{~d}$.

There were no differences in the number of corpora lutea, or in total conceptus, ovarian or placental weights on day 19 of pregnancy (Table 5). Mean fetus weights of rats fed diet $\mathrm{P}$ were significantly smaller $(1.96 \mathrm{~g})$ than rats fed $\mathrm{H}, \mathrm{PP}$ and $\mathrm{ICN}(2 \cdot 11,2 \cdot 10$ and $2 \cdot 14 \mathrm{~g}$, respectively) $\left(F_{(4,45)}=8.47 ; P<0.001\right)$.

\section{Discussion}

\section{Growth}

Our study was conducted to determine whether the physiological changes observed in the declining population of Steller sea lions could be caused by the consumption of walleye pollock (a dominant prey of Steller sea lions in Alaska). One of those changes in sea lions was reduced body size (weight and volume) as compared with pre-decline measurements when pollock consumption was

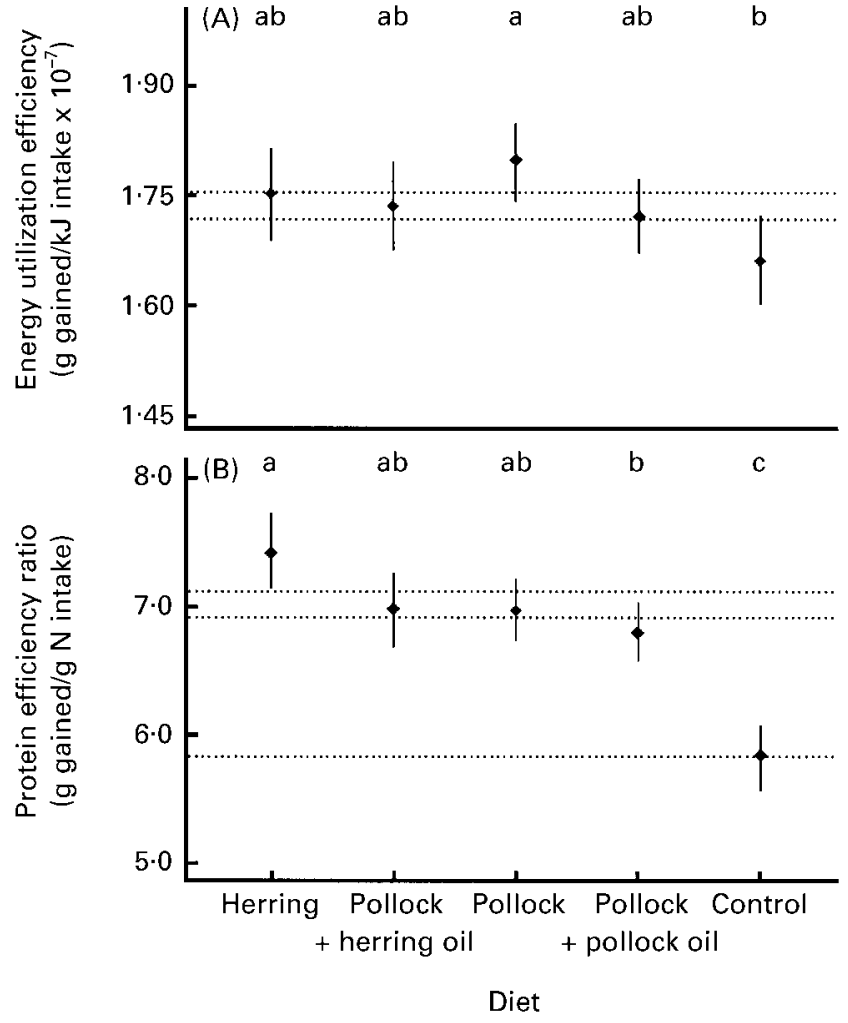

Fig. 6. Mean efficiencies of energy utilization (A) and protein efficiency $(B)$ ratios of rats fed different fish diets or control diet. Vertical bars are $95 \%$ confidence intervals ( $n 12$ rats/group). Mean values with unlike letters were significantly different $(P=0.027$ for energy utilization efficiency; $P<0.001$ for protein efficiency ratio). $(\cdots)$, Means of statistically similar groups.

lower (Calkins et al. 1998). In our study, we found that all groups of rats fed fish diets (regardless of oil content or source) had statistically similar growth before reproduction. However, mean growth curves showed a uniform trend, with rats fed herring $(\mathrm{H})$ being consistently heavier than those fed pollock supplemented with herring oil $(\mathrm{PH})$, who were in turn heavier than those fed pollock (P) and pollock supplemented with its own oil (PP)

Table 5. Reproductive and tissue parameters of rats, taken at killing on day 19 of pregnancy, fed different fish diets or a semipurified control diet

(Mean values with their standard errors)

\begin{tabular}{|c|c|c|c|c|c|c|c|c|c|c|}
\hline & \multicolumn{2}{|c|}{ Herring (n 11) } & \multicolumn{2}{|c|}{$\begin{array}{l}\text { Pollock + herring } \\
\quad \text { oil }(n 11)\end{array}$} & \multicolumn{2}{|c|}{ Pollock (n 11) } & \multicolumn{2}{|c|}{$\begin{array}{l}\text { Pollock + pol- } \\
\text { lock oil (n 9) }\end{array}$} & \multicolumn{2}{|c|}{ Control (n9) } \\
\hline & Mean & SE & Mean & SE & Mean & SE & Mean & SE & Mean & SE \\
\hline Food intake $(g / g)^{*}$ & 0.063 & 0.002 & 0.061 & 0.002 & 0.065 & 0.001 & 0.062 & 0.002 & 0.066 & 0.003 \\
\hline Energy Intake $(\mathrm{kJ} / \mathrm{g})^{*}$ & 1.28 & 10.94 & 1.27 & $10 \cdot 76$ & 1.20 & $7 \cdot 1$ & $1 \cdot 29$ & $9 \cdot 26$ & $1 \cdot 23$ & $13 \cdot 5$ \\
\hline Mean fetus weight (g) & $2 \cdot 11^{\mathrm{b}}$ & 0.03 & $2 \cdot 02^{\mathrm{ab}}$ & 0.02 & $1.96^{\mathrm{a}}$ & 0.03 & $2 \cdot 10^{\mathrm{b}}$ & 0.02 & $2 \cdot 14^{b}$ & 0.02 \\
\hline Conceptus weight $(\mathrm{g}) \dagger$ & $54 \cdot 12$ & 3.53 & $51 \cdot 00$ & $4 \cdot 11$ & 51.92 & 3.06 & $47 \cdot 74$ & 5.45 & $52 \cdot 51$ & 3.88 \\
\hline Corpora lutea (no.) & $16 \cdot 63$ & 0.74 & $17 \cdot 09$ & 0.44 & $15 \cdot 70$ & 0.75 & $15 \cdot 56$ & 0.75 & 14.78 & $1 \cdot 15$ \\
\hline Ovarian weight $(\mathrm{g}) \ddagger$ & 0.20 & 0.01 & 0.23 & 0.02 & 0.22 & 0.02 & 0.21 & 0.06 & 0.20 & 0.02 \\
\hline Placental weight $(\mathrm{g}) \S$ & $5 \cdot 40$ & 0.30 & $5 \cdot 01$ & 0.39 & $5 \cdot 35$ & 0.33 & $4 \cdot 74$ & 0.52 & 5.04 & 0.33 \\
\hline
\end{tabular}

a,b Mean values within a row with unlike superscript letters were significantly different $(P<0.05)$

${ }^{*}$ Mass-corrected mean daily intake or daily energy intake from day 1 to day 19 of gestation.

† Weight of all fetuses, uterus, ovaries and uterine fluids.

$\ddagger$ Mean of left and right ovary.

$\S$ Mean weight of all placentas/female. 

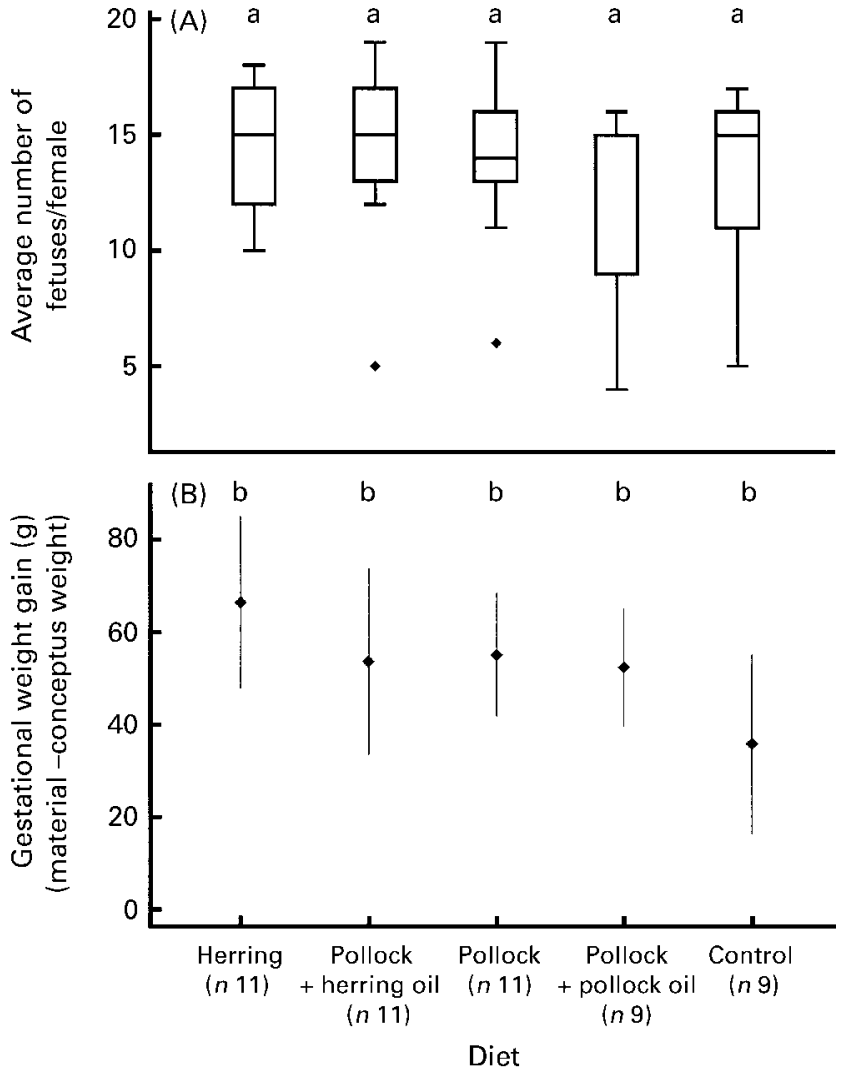

Fig. 7. Litter size (A) and maternal weight gain (B) of female rats (nine to eleven rats/group) fed different diets. The horizontal line within each box plot indicates the median average number of fetuses/female. Gestational weight gains equal the maternal weight gained during pregnancy minus the weight of the uterus, fetuses and all fluids, and are shown as means with $95 \%$ confidence intervals represented by vertical bars. Differences between means were not statistically significant.

(Figs. 2 and 3). Power analysis indicates that such differences would be statistically significant if we increased our sample size from twelve to twenty-two rats/treatment group. Whether this trend was truly insignificant, or whether it reflects differences in the quality of fat, the quality of the fish proteins, or the amount of fat present in the diets, is debatable.

Growth curves similar to those we obtained have resulted from other studies that fed rats fat-free basal diets supplemented with $10 \%$ menhaden, tuna or herring oil (Privett et al. 1960), thereby supporting the notion that fish oils from a range of marine species are a complete source of essential fatty acids (Stansby, 1969). Thus, differences in the growth of our rats were not entirely attributed to fat quality, as defined by the fatty acid composition of the fish oils, nor by the digestibility of the lipids.

Differences in the quality of dietary protein were not obvious from the pre-pregnancy growth curves. Herring protein has been shown to be superior in its ability to promote growth as compared with seventeen other species of fish protein, including salmon, tuna and halibut (Nilson et al. 1947). Differences in protein quality in our study became more pronounced after reproduction (Fig. 3). By this time, the rats that received herring seemed to be heavier than those that received pollock, regardless of the type of oil or the amount of oil consumed with the pollock protein.

The $\mathrm{P}$ and the ICN diets contained about $8 \%$ less fat than the herring and supplemented pollock diets (PP and $\mathrm{PH})$. However, the growth of the rats fed diet $\mathrm{P}$ was higher than the ICN group. This suggests that the fat content of pollock did not limit growth because the rats compensated for the lower energy density of the diets by increasing their food intakes.

\section{Food intake}

Food intake of rats fed the low-energy diets (P and ICN) was greater than those fed the other three diets, and resulted in equal energy consumption among all groups (Fig. 5). This compensation response is consistent with other studies that have shown that rats can regulate the type and amount of food they consume to meet nutritional demands.

Theories regarding the mechanisms controlling energy intake are complex and include: (1) food intake is based on the fat content of the food source (Burton-Freeman et al. 1999); (2) the 'depletion-repletion' model which states that feeding is initiated when blood or brain levels of metabolites such as glucose or cholecystokinin, termed appetostats, fall below a certain threshold level (for reviews, see Johnson et al. 1986; Ackroff \& Sclafani, 1996); (3) that energy intake is regulated over a span of several meals or days, by long-term controls of energy balance and adiposity (Johnson et al. 1986; Beck et al. 1990). These include pathways involving leptin, insulin and neuropeptide $\mathrm{Y}$ which can override shorter-term satiety cues such as glucose and gastric peptides to maintain energy balance (Schwartz et al. 1999).

Our finding that rats increased their intake of pollock to compensate for its low energy density is important. To date, there is no evidence that young Steller sea lions can or will increase their intake of pollock to compensate for a less energetically dense food source. Indeed, one study found that they may lose body mass on ad libitum pollock diets (about $0.6 \mathrm{~kg} / \mathrm{d}$ ) (Rosen \& Trites, 2000b). Juvenile harp seals switched from a diet of high-energy Atlantic herring to low-energy Atlantic pollock also did not increase the amount of food they consumed to make up for the energy density of the two prey species. Instead of losing mass, however, they lost $32 \%$ of their fat reserves and gained lean body mass (Kirsch et al. 2000). Young mink fed low-fat gadids such as cod, haddock, whiting and hake, have been shown to increase their food intake to compensate for low energy (Leoschke, 1961). However, their growth was still retarded compared with those fed higher-fat fish, the optimal fat content being approximately $25 \%$ for this aquatic mammal (Leoschke, 1961). The ability of rats to compensate for low-energy pollock diets and maintain satisfactory growth suggests that there is either a palatability issue, or that there are innate differences in food intake and satiation regulation in sea lions and other mammals. It is also possible that the feeding studies with captive Steller sea lions have not been sufficiently long enough to determine if low palatability of pollock (if this is indeed a factor) can be overridden by energetic demands. 
If increased intake of pollock were physiologically possible for young sea lions, there would be an enormous energetic cost to this increase. Estimates derived from the energetic compositions of herring and pollock, the heat increments of feeding of both diets, digestive efficiencies and urinary energy losses have suggested that sea lions would require $35-80 \%$ more pollock than herring to maintain equal net energy intakes (Rosen \& Trites, $2000 b$ ). However, such an increase may not be feasible for an animal that travels up to $350 \mathrm{~km} /$ foraging trip (Merrick et al. 1995). Proximate analyses of the fish used in our study indicate that a sea lion would require $60 \%$ more pollock than herring, which falls well within the range outlined by Rosen \& Trites $(2000 \mathrm{~b})$, assuming the same digestive efficiencies, urinary losses and heat increment of feeding.

\section{Diet quality}

The fatty acid profiles of the diets used in our study (Table 3 ) are similar to profiles in the literature for both herring and maize oil (Stansby, 1969, 1986; Mehta et al. 1994). A profile for pollock oil was not found. As is the case with all fish species, fatty acid content can vary substantially across individuals, time, geographic area and season as the diet of the fish changes (Stansby, 1986). We did not attempt to describe a 'typical' fatty acid profile for pollock or herring with these values. However, our fatty acid profiles should be sufficient given that our study attempted only to evaluate the diet fed to our rats and assess the presence or absence of essential fatty acids.

According to the National Academy of Sciences, the minimum requirement for linoleic acid (18:2n-6), an essential fatty acid in rats, is $0.24 \%$ of energy in the diet (assuming $17 \mathrm{~kJ} / \mathrm{g}$ diet) (Warner \& Breuer, 1972). The diet containing the lowest quantity of linoleic acid in our study was $\mathrm{PH}$, which contained $0.3 \%$ linoleic acid and was above the minimum requirement.

Despite linoleic acid quantities in the ICN diet being almost fifty times higher than the fish diets, the ICN group exhibited reduced growth and slightly smaller litter sizes. The ICN diet contained solely maize oil, which was relatively low in polyunsaturated fatty acids such as arachidonic acid (20:4n-6), eicosapentaenoic acid and docosahexaenoic acid. These are considered by some to be essential fatty acids due to the low efficiencies of conversion from linoleic and linolenic acid (Arrington, 1978; Arts et al. 2001). Docosahexaenoic acid and eicosapentaenoic acid are crucial to the brain and neural development of fetuses and neonates, and to normal retinal function, the regulation of eicosanoid formation, and healthy heart and joint functioning (Dratz \& Deese, 1986; Lands, 1986; Weber et al. 1986; Holman, 1997; Arts et al. 2001).

Given the high variability of fatty acid contents between individual fish, and the variation that probably occurs over time and space, the significance of the differences between pollock and herring are not known. As of yet, there are no defined 'healthy' upper and lower limits established for many components of the diet. The fact that the pollock diet strays farther from the recommended 1:4 ratio
(Holman, 1997) of n-3:n-6 fatty acids (15·1 v. 7.71 for herring) may indicate an imbalance in these fish, but the ratio for herring is far from 0.25 as well. On the other hand, pollock contained twice as much docosahexaenoic acid and eicosapentaenoic acid as herring. Unfortunately, this does not explain the relatively reduced growth and litter sizes of the pollock + pollock oil (PP) rats, and the reduced fetal weights of the pollock $(\mathrm{P})$ rats. A comparison of the digestibility and retention of the different oils may prove useful in answering these questions in the future, as well as tissue analyses of the fetuses.

The essential amino acid content of all diets was relatively complete, and in agreement with literature values (Jacquot, 1961). Slightly lower levels of phenylalanine and isoleucine in the supplemented pollock diets (as compared with the dietary requirements of rats) are probably not biologically relevant. The published amino acid requirements for rats can vary by approximately $25 \%$ depending on the reference used, and these are generally considered conservative levels (Mitchell, 1955; Warner \& Breuer, 1972).

The efficiency of energy use by rats consuming the pollock (P) and supplemented pollock diets (PH and PP) was consistent with other studies that have compared high-fat and low-fat diets. Supplementing a diet with fat reduces the efficiency of energy utilization (Harris, 1991; Iossa et al. 1997). The addition of pollock or herring oil to the pollock diet could have decreased the viscosity of the meal. Passage rate through the gut has been shown to decrease with decreasing viscosity, and can affect the absorption of essential nutrients such as amino acids in growing rats (Larsen et al. 1994). The addition of oil to these two diets, therefore, may have reduced passage rate and allowed less time for energy absorption in the gut. This may not have been seen in the herring group as the fat in this diet was present in the freeze-dried herring, and not added in a liquid state.

Other measures of efficiency have been tested in Steller sea lions eating various fish diets. Digestive efficiency, measured as the percentage of energy absorbed from a diet, has been shown to be highest for herring when compared with pollock, salmon and squid (Rosen \& Trites, 2000a).

The high protein efficiency ratio for herring supports the results of Nilson et al. (1947) who found that protein efficiency for herring was the highest $(2 \cdot 31)$ among seventeen species of fish (mean, 2.05).

Comparing Figs. 3 and 6 shows a similar trend between total weight gain and protein efficiency ratio. This suggests that protein quality, or the efficiency with which an animal can assimilate its protein, is a major limiting factor in the growth of weanling animals and pregnant females. It has been shown that the effects of protein deficiencies are much more pronounced in young rats than in adult rats, and especially during pregnancy and lactation when protein requirements are increased (Widdowson, 1981; de Mello \& Cury, 1989; Krajcivicova-Kudlackova \& Dibak, 1991). Despite the fact that energy consumption was equal in all groups, by the end of our study, their growth seems to have been limited by the quality of the protein. 


\section{Reproduction}

Nutritional deficiencies have been shown to delay the onset of puberty through reduced circulating leptin, the hormone peptide of the $o b / o b$ gene. Leptin, in turn, alters levels of circulating gonadotropin-releasing hormone and luteinizing hormone, which control pubertal onset (Bronson, 1988; Carlsson et al. 1997; Chehab et al. 1997; Cheung et al. 1997). The initiation of puberty, as determined by vaginal opening, occurs at approximately $42 \mathrm{~d}$ of age in Wistar rats (Bennet \& Vichery, 1970). There was no significant difference in the age at vaginal opening among treatment groups, the mean being approximately $43 \mathrm{~d}$.

However, vaginal opening does not necessarily coincide with the first oestrus period, with possible lags between vaginal opening and the first ovulation being as long as $7 \mathrm{~d}$ (Zhang et al. 1992). A difference between dietary groups may have been overlooked because daily vaginal smears were not taken.

The National Research Council's recommended energy intake for pregnant rats is approximately $318 \mathrm{~kJ} / \mathrm{d}$, which represents a $50 \mathrm{~kJ} / \mathrm{d}$ increase above normal growth requirements (Warner \& Breuer, 1972). All rats in our study ate beyond this requirement (mean, $439 \mathrm{~kJ} / \mathrm{d}$ ) and there was no significant difference in the mass-corrected intakes, or the energy intakes between groups.

The greatest energy requirements for female mammals occur during lactation (Warner \& Breuer, 1972; Widdowson, 1981). For the laboratory rat, required food intake can increase by nearly four times the amount eaten at parturition (Widdowson, 1981) and recent modelling exercises have estimated increased energy requirements of sea lions during lactation to be twice as much at weaning (almost 1 year after birth) (Winship et al. 2002). Nutritional stress during lactation can result in reduced milk yield and is especially critical under protein deficiencies (Widdowson, 1981; McGuire et al. 1995). Any form of environmental constraint on food acquisition, therefore, would have greater impacts on mothers and pups during lactation than during gestation (Veloso \& Bozinovic, 2000). This is relevant to both our study and to Steller sea lions in the wild. Ideally, our experiment should have continued through lactation to assess the ability of mothers to feed their pups. Pup mortality during the first days of life is another common indicator of reproductive success and would have been a useful parameter in our study (Shaw et al. 1997). In mammals such as seals that undergo fasts after parturition, survival of the pups to weaning is closely correlated with the mother's nutritional status. Thus nutrition directly determines reproductive success (Follett, 1982).

The mean gestational weight gain for all rats in our study was $53.1 \mathrm{~g}$, and was similar to gains attained in other studies that used similarly-aged Wistar rats (mean, 52.9 g; (Yonekubo et al. 1993). The differences in gestational weight gain between diets were not significant, but there was a trend towards lower gain in all pollock-eating groups (P, PP and $\mathrm{PH}$ ), and especially for the ICN group (Fig. 7 (B)). This trend in weight gain was similar to that of the protein efficiency ratios, again implying that protein quality was a limiting factor during pregnancy.
The increasing demands of pregnancy and lactation on a mother are most often met with increasing food intake. But when resources are limited, mothers may use a number of strategies to reduce the impact of a food shortage (Veloso \& Bozinovic, 2000). These include altering the length of gestation, the duration of lactation, the size of the litter and/or the body mass of her fetus(es).

There is some debate over whether small mothers tend to have multiple offspring with lower birth weights (de Mello \& Cury, 1989; Abel, 1990; Olsen et al. 1990; Sohlstrom et al. 1994), or whether they have reduced litter sizes (Rowlands \& Weir, 1984; McGuire et al. 1995). The smallest (in weight) in our study was the ICN group, which had slightly fewer, yet larger pups. The PP group had slightly reduced litter sizes, and the $\mathrm{P}$ group had significantly reduced pup weights. Our data do not exclusively support either hypothesis. However, for the purpose of our study, the specific mechanism of reproductive compensation is less important than the overall reproductive success of the rats in each group. Sea lions are uniparous mammals, limiting their possible reproductive compensations to small offspring at greater risk of mortality and infection, or missed reproductive events. The reasons why the fetuses of rats fed pollock (P) weighed less are unknown, but the inferior quality of pollock protein as seen from reduced protein efficiency ratios could have contributed to this, and is relevant when considering Steller sea lion ecology.

There is evidence that even if food intake is adequate during pregnancy, undernutrition early in life (in utero and during weaning) can result in smaller litter sizes, litter weights and reduced milk yield during lactation later in life (McGuire et al. 1995). Population growth could thus be affected for generations after a populationwide food shortage. Additionally, although low-birthweight pups may be able to make up mass during suckling and adolescence if food supply is adequate, deficiencies early in life may result in permanently smaller skeletal structures (Ohlsson \& Smith, 2001). This can have drastic repercussions for males that compete with other males for mates and territories; size being a critical characteristic in these competitions (Ohlsson \& Smith, 2001).

The effect of maternal nutrition on the growth of fetus(es) depends not only on the degree of undernutrition, but also on the timing of undernutrition and the species involved (Widdowson, 1981). Generally, the longer the gestational period, the more pronounced the effect of undernutrition on the fetus(es). The effects on the rat, with a $21 \mathrm{~d}$ gestation, are therefore relatively minor (Widdowson, 1981) and may buffer fetuses and mothers from deficiencies. Even the guinea-pig, with a $67 \mathrm{~d}$ gestation, is more severely affected by food shortages during gestation than the rat (Widdowson, 1981). Reducing a pregnant guinea-pig's food during the latter part of gestation can halve the weight of her offspring. For an animal such as the Steller sea lion, with a gestation length of over 8 months (Rowlands \& Weir, 1984), the possible consequences of nutritional deficiencies on their pups could be much more drastic than those we observed in our animal model. This may be further exacerbated by the fact that mature females are often still nursing pups 
from the previous year during pregnancy (Pitcher, 1981; Pitcher et al. 1998).

Our study focused solely on the effects of undernutrition on the reproductive health of the female rat and her pups. Paternal undernutrition can also affect reproductive events in mammals. Low food availability has been shown to reduce libido, prostate fluid production, sperm counts, sperm motility, and the rate of successful matings (Blank \& Desgardins, 1984; Abel, 1990). For animals that mate only once a year, food shortages during the mating period could seriously affect the next year's pup counts by reducing the number of successful breeding events. However, because the greatest energy investment into reproduction comes from the female and involves much longer spans of investment (Short, 1982), food shortages and their effects are more likely to alter reproductive success through the female's contribution.

\section{Steller sea lions}

The objective of our study was to evaluate the quality of two different species of fish to gain insight into the nutritional effects of these species on Steller sea lions. A number of our findings using the rat model may provide further insights into the hypothesis that diets dominated by pollock have contributed to the decline of Steller sea lions in the Gulf of Alaska.

The quality of pollock and herring were determined partially through comparisons between the fatty acid and amino acid contents of the fish, and those required by the rat. The specific requirements for these components are known for very few species, and little is known about what is 'essential' for Steller sea lions or other marine mammals. We thus assumed that the nutrients that are considered essential for other mammals (except linoleic acid) are also those that are essential for sea lions (Warner \& Breuer, 1972).

Concern over the low energy density of pollock has fuelled feeding studies that monitored the body mass of captive Steller sea lions fed pollock and herring (Rosen $\&$ Trites, 1997, 2000a,b). These studies found sea lions increased body mass while consuming herring $(0.2 \mathrm{~kg} / \mathrm{d})$, but lost mass (about $0.6 \mathrm{~kg} / \mathrm{d}$ ) while eating pollock (Rosen \& Trites, 2000b). Additionally, the heat increment of feeding, or the energy used to digest meals, was higher for pollock than for herring (Rosen \& Trites, 1997).

Rats were able to compensate for the difference in energy content of the fish diets by increasing their food intakes. To date, young Steller sea lions have not yet demonstrated that they can increase their intake (Rosen $\&$ Trites, 2000b). This may be a critical difference between the two species of mammals.

Assuming compensation could occur in the sea lions, one must assume that this would entirely satisfy their requirements and that there are no other differences between the fish. However, the quality of pollock protein and oil seem to be lower than herring, as seen in the slightly reduced growth and reproductive success of the PP rats. Mink fed low-fat gadids were able to increase their intake to make up for the low fat content of pollock, but were still unable to attain growth equal to that of mink eating higher-fat fish (Leoschke, 1961).

Despite similar litter sizes, fetuses of rats fed pollock were significantly lighter than those fed $\mathrm{H}$, PP, or the ICN diet. In other mammals, low birth weights have been associated with high incidence of mortality and increased risk of infection and illness (Bulik et al. 1999). If small pups are able to survive, they may still be at risk of reduced competitive fitness and reproductive success due to smaller skeletal structures, as discussed earlier (McGuire et al. 1995; Ohlsson \& Smith, 2001). Presently, there is no evidence of reduced pup size in Steller sea lions. On the contrary, pups in the declining populations appear to be larger than in the increasing populations (Castellini et al. 1993; Merrick et al. 1995; Rea, 1995). However, pup counts have steadily declined on rookeries during the last 30 years (Trites \& Larkin, 1996). It is possible that either reproduction is failing earlier, in pregnancy (Calkins $\&$ Goodwin, 1988), or the effects of poor quality food are being felt after weaning in the juveniles who are no longer buffered from nutritional deficiencies by their mothers. Presently, sea lions do not eat a diet of $100 \%$ pollock, so the negative effects of a pollock diet may be partially buffered by consuming other species of fish. There is evidence that the more heavily a diet is concentrated on pollock, the greater the population decline of the Steller sea lions (Merrick et al. 1997).

\section{Conclusions}

Difficulties in conducting controlled experiments on Steller sea lions have made it necessary to develop alternative animal models for use in sea lion research to understand the consequences of consuming different species of fish. The results of our study indicate that the primary shortcoming of pollock for rats is its low energy density. Additionally, however, there is evidence of a relatively poor protein quality in pollock that, in combination with a low energy density, may have repercussions on reproductive success. The consequences of these characteristics could ultimately contribute to the documented decrease in Steller sea lion body size (Calkins \& Pitcher, 1982; Calkins \& Goodwin, 1988), and may slow the recovery of sea lion populations that consume primarily pollock.

\section{Acknowledgements}

We are grateful to At-Sea-Processors, Grant Saar at West Coast Reductions, and the Vancouver Aquarium Marine Science Center for providing the fish and fish oil for the present study. We also appreciated the prompt services and attention to detail of Pleasant Valley Freeze Dry. We thank Sherman Yee for his help with all of the laboratory equipment and Gilles Galzi, Katie Du, Dr Raja Rajamahedran and Muhammad Aali for their expertise and analyses of the diets. Comments and suggestions from Ken Pitcher, Dr Bill Milsom and Dr Jim Thompson improved our study and are gratefully acknowledged. Financial support was provided by NOAA and the North Pacific Marine Science Foundation through the North Pacific Universities Marine Mammal Research Consortium. 


\section{References}

Abel EL (1990) Effects of paternal and maternal undernutrition on growth of offspring in rats. Growth, Development and Aging 54, 125-129.

Ackroff K \& Sclafani A (1996) Rats integrate meal cost and postoral changes in caloric density. Physiology and Behavior 60, 927-932.

Alaska Sea Grant (1993) Is it Food? Addressing Marine Mammal and Seabird Declines, pp. 59. Fairbanks, AK: Alaska Sea Grant College Program.

Alverson DL (1992) A review of commercial fisheries and the Steller sea lion (Eumetopias jubatus): the conflict arena. Reviews in Aquatic Sciences 6, 203-256.

AOAC (2000) Official Method 965.33. Official Methods of Analysis of the Association of Official Analytical Chemists. Washington DC: AOAC.

Arrington LR (1978) Introductory Laboratory Animal Science; The Breeding, Care and Management of Experimental Animals, 2nd ed, Danville, IL: The Interstate Printers and Publishers, Inc.

Arts MT, Ackman RG \& Holub BJ (2001) "Essential fatty acids" in aquatic ecosystems: a crucial link between diet and human health and evolution. Canadian Journal of Fisheries and Aquatic Science 58, 122-137.

Beck B, Strickler-Krongrad A, Burlet A, Nicolas J-P \& Burlet C (1990) Influence of diet composition on food intake and hypothalamic neuropeptide Y (NPY) in the rat. Neuropeptides $\mathbf{1 7}$ 197-203.

Bennet JP \& Vichery BH (1970) Rats and mice. In Reproduction and Breeding Techniques for Laboratory Animals, pp. 299-315 [ESE Hafez, editor]. Philadelphia: Lea \& Febiger.

Benson AJ \& Trites AW (2002) A review of the effects of regime shifts on the production domains in the eastern North Pacific Ocean. Fish and Fisheries 3, 95-113.

Blank JL \& Desgardins C (1984) Spermatogenesis is modified by food intake in mice. Biology of Reproduction 30, 410-415.

Bronson FH (1988) Effect of food manipulation on the GnRHLH-estradiol axis of young female rats. American Journal of Physiology 254, R616-R621.

Bulik CM, Sullivan PF, Fear JL, Pickering A, Dawn A \& McCullin M (1999) Fertility and reproduction in women with anorexia nervosa: a controlled study. Journal of Clinical Psychiatry 60, 130-135.

Burton-Freeman B, Gietzen DW \& Schneeman BO (1999) Cholecystokinin and serotonin receptors in the regulation of fatinduced satiety in rats. American Journal of Physiology 276, R429-R434.

Calkins DG, Becker EF \& Pitcher KW (1998) Reduced body size of female Steller sea lions from a declining population in the Gulf of Alaska. Marine Mammal Science 14, 232-244.

Calkins DG, McAllister DC \& Pitcher KW (1999) Steller sea lions status and trend in southeast Alaska: 1979-1997. Marine Mammal Science 15, 462-477.

Calkins DG \& Pitcher KW (1982) Population Assessment, Ecology, and Trophic Relationships of Steller Sea Lions in the Gulf of Alaska, pp. 546. Anchorage, AK: Alaska Department of Fish and Game.

Calkins P \& Goodwin E (1988) Investigation of the Declining Sea Lion Population in the Gulf of Alaska, pp. 76. Anchorage, AK: Alaska Department of Fish and Game.

Carlsson B, Ankarberg C, Rosberg S, Norjavaara E, AlbertssonWikland K \& Carlsson LMS (1997) Serum leptin concentrations in relation to pubertal development. Archives of Disease in Children 77, 396-400.

Castellini MA, Davis RW, Loughlin TR \& Williams TM (1993) Blood chemistries and body condition of Steller sea lion pups at Marmot Island, Alaska. Marine Mammal Science 9, 202-208.

Chehab FF, Mounzih K, Lu R \& Lim ME (1997) Early onset of reproductive function in normal female mice treated with leptin. Science 275, 88-90.

Cheung CC, Thornton JE, Kuijper JL, Weigle DS, Clifton DK \& Steiner RA (1997) Leptin is a metabolic gate for the onset of puberty in the female rat. Endocrinology 138, 855-858.

de Mello MAR \& Cury L (1989) Influence of protein-calorie malnutrition on reproductive performance of young and mature rats. Growth, Development and Aging 53, 141-144.

Dratz EA \& Deese AJ (1986) The role of docosahexaenoic acid (22:6n-3) in biological membranes: examples from photoreceptors and model membrane bilayers. In Health Effects of Polyunsaturated Fatty Acids in Seafoods, [AP Simopoulos, RR Kifer and RE Martin, editors]. Orlando, FL: Academic Press.

Folch J, Lees M \& Sloane-Stanley GH (1957) A simple method for the isolation and purification of total lipides from animal tissues. Journal of Biological Chemistry 226, 497-509.

Follett BK (1982) The environment and reproduction. In Reproductive Fitness, pp. 103-132 [CR Austin and RV Short, editors]. Cambridge: Cambridge University Press.

Harris RBS (1991) Growth measurements in Sprague-Dawley rats fed diets of very low fat concentration. Journal of Nutrition 121, 1075-1080.

Holman RT (1997) $\omega 3$ and $\omega 6$ essential fatty acid status in human health and disease. In Handbook of Essential Fatty Acid Biology: Biochemistry, Physiology, and Behavioral Neurobiology, pp. 139-181 [S Yehuda and DI Mostofsky, editors]. Totowa, NJ: Humana Press Inc.

Iossa S, Mollica MP, Lionetti L, Barletta A \& Liverini G (1997) Energy balance and liver respiratory activity in rats fed on an energy-dense diet. British Journal of Nutrition 77, 99-105.

Jacquot R (1961) Organic constituents of fish and other aquatic animal foods. In Fish as Food: Production, Biochemistry, and Microbiology, pp. 145-209 [G Borgstrom, editor]. New York: Academic Press.

Johnson DR, Ackroff K, Peters J \& Collier GH (1986) Changes in rats' meal patterns as a function of the caloric density of the diet. Physiology and Behavior 36, 929-936.

Kirsch PE, Iverson SJ \& Bowen WD (2000) Effect of a low-fat diet on body composition and blubber fatty acids of captive juvenile harp seals (Phoca groenlandica). Physiological and Biochemical Zoology 73, 45-49.

Krajcivicova-Kudlackova M \& Dibak O (1991) Utilization of qualitatively different proteins in relation to age and high fat intake under experimental conditions. Ceskslovenska Gastroenterologie a Vyziva 45, 27-34.

Lands WEM (1986) The fate of polyunsaturated fatty acids. In Health Effects of Polyunsaturated Fatty Acids in Seafoods, pp. 33-48 [AP Simopoulos, RR Kifer and RE Martin, editors]. Orlando, FL: Academic Press.

Larsen FM, Wilson MN \& Moughan PJ (1994) Dietary fiber viscosity and amino acid digestibility, proteolytic digestive enzyme and digestive organ weight in growing rats. Journal of Nutrition 124, 833-841.

Leoschke WL (1961) Fish in the raising of mink. In Fish as Food, pp. 435-441 [G Borgstrom, editor]. New York: Academic Press.

McGuire MK, Littleton AW, Schulze KJ \& Rasmussen KM (1995) Pre- and postweaning food restrictions interact to determine reproductive success and milk volume in rats. Journal of Nutrition 125, 2400-2406.

Mehta RS, Gunnett CA, Harris SR, Bunce OR \& Hartle DK (1994) High fish oil diet increases oxidative stress potential 
in mammary gland of spontaneously hypertensive rats. Clinical and Experimental Pharmacology and Physiology 21, 881-889.

Merrick RL, Brown R, Calkins DG \& Loughlin TR (1995) A comparison of Steller sea lion, Eumetopias jubatus, pup masses between rookeries with increasing and decreasing populations. Fisheries Bulletin 93, 738-758.

Merrick RL \& Calkins DG (1996) Importance of juvenile walleye pollock, Theragra chalcogramma, in the diet of Gulf of Alaska Steller sea lions, Eumetopias jubatus. pp. 153-166. Seattle: National Marine Fisheries Service, NOAA.

Merrick RL, Chumbley MK \& Byrd GV (1997) Diet diversity of Steller sea lions (Eumetopias jubatus) and their population decline in Alaska: a potential relationship. Canadian Journal of Fisheries and Aquatic Science 54, 1342-1348.

Mitchell HH (1955) Some species and age differences in amino acid requirements. In Protein and Amino Acid Requirements of Mammals, [AA Albanese, editor]. New York: Academic Press.

Muller HG \& Tobin G (1980) Nutrition and Food Processing. Westport, CT: The AVI Publishing Company, Inc.

Nilson HW, Martinek WA \& Jacobs B (1947) Nutritive value for growth of some fish proteins. Commercial Fisheries Review $\mathbf{9}$, $1-7$.

Nwokolo E \& Kitts DD (1988) Growth parameters and plasma and tissue fatty acid profiles in rats fed rubber seed oil. Food Chemistry 30, 219-229.

Ohlsson T \& Smith HG (2001) Early nutrition causes persistent effects on pheasant morphology. Physiological and Biochemical Zoology 74, 212-218.

Olsen SF, Hansen HS \& Jensen B (1990) Fish oil versus arachis oil food supplementation in relation to pregnancy duration in rats. Prostaglandins, Leukotrienes and Essential Fatty Acids 40, 255-260.

Pitcher KW (1981) Prey of the Steller sea lion, Eumetopias jubatus, in the Gulf of Alaska. Fishery Bulletin 79, 467-472.

Pitcher KW, Calkins DG \& Pendleton GW (1998) Reproductive performance of female Steller sea lions: an energetics-based reproductive strategy? Canadian Journal of Zoology 76, 2075-2083.

Privett OS, Pusch FJ, Holman RT \& Lundberg WO (1960) Essential fatty acid properties of tuna, herring and menhaden oils. Journal of Nutrition 71, 66-69.

Rea L (1995) Prolonged fasting in pinnipeds, $\mathrm{PhD}$ thesis, University of Alaska at Fairbanks.

Rosen DAS \& Trites AW (1997) Heat increment of feeding in Steller sea lions, Eumetopias jubatus. Comparative Biochemistry and Physiology 118A, 877-881.

Rosen DAS \& Trites AW (2000a) Digestive efficiency and drymatter digestibility in Steller sea lions fed herring, pollock, squid, and salmon. Canadian Journal of Zoology 78, 1-6.

Rosen DAS \& Trites AW (2000b) Pollock and the decline of Steller sea lions: testing the junk food hypothesis. Canadian Journal of Zoology 78, 1243-1250.

Ross PS, de Swart RL, van der Vliet H, Willemsen L, de Klerk A, van Amerongen G, Groen J, Brouwer A, Schipholt I, Morse DC, van Loveren H, Osterhaus ADME \& Vos JG (1997) Impaired cellular immune response in rats exposed perinatally to Baltic Sea herring oil or 2,3,7,8-TCDD. Archives of Toxicology 17, 563-574.

Ross PS, Van Loveren H, de Swart RL, van der Vliet H, de Klerk A, Timmerman JJ, van Binnendijk R, Brouwer A, Vos JG \&
Osterhaus ADME (1996) Host resistance to rat cytomegalorvirus (RCMV) and immune function in adult PVG rats fed herring from the contaminated Baltic Sea. Archives of Toxicology 70, 661-671.

Rowlands IW \& Weir BJ (1984) Mammals: non-primate eutherians. In Marshall's Physiology of Reproduction, pp. 455-658 [GE Lamming, editor]. New York, NY: Churchill Livingstone.

Schwartz MW, Baskin DG, Kaiyala KJ \& Woods SC (1999) Model for the regulation of energy balance and adiposity by the central nervous system. American Journal of Clinical Nutrition 69, 584-596.

Shaw MA, Rasmussen KM \& Myers TR (1997) Consumption of a high fat diet impairs reproductive performance in SpragueDawley rats. Journal of Nutrition 187, 64-69.

Short RV (1982) Species differences in reproductive mechanisms. In Reproductive Fitness, pp. 24-61 [CR Austin and RV Short, editors]. Cambridge: Cambridge University Press.

Sohlstrom A, Kabir N, Sadurskis A \& Forsum E (1994) Body composition and fat distribution during the first 2 weeks of gestation in ad lib.-fed and energy-restricted rats. British Journal of Nutrition 71, 317-333.

Stansby ME (1969) Nutritional properties of fish oils. World Review of Nutrition and Dietetics 11, 46-105.

Stansby ME (1986) Fatty acids in fish. In Health Effects of Polyunsaturated Fatty Acids in Seafoods, pp. 389-401 [AP Simopoulos, RR Kifer and RE Martin, editors]. Orlando, FL: Academic Press.

Trites AW \& Larkin PA (1996) Changes in the abundance of Steller sea lions (Eumetopias jubatus) in Alaska from 1956 to 1992: how many were there? Aquatic Mammals 22, $153-166$.

Trites AW, Livingston PA, Vasconcellos MC, Mackinson S, Springer AM \& Pauly D (1999) Ecosystem change and the decline of marine mammals in the Eastern Bering Sea: testing the ecosystem shift and commercial whaling hypotheses. 7(1) pp. 106. Vancouver: Fisheries Center, UBC.

Veloso C \& Bozinovic F (2000) Effect of food quality on the energetics of reproduction in a precocial rodent, Octodon degus. Journal of Mammalogy 81, 971-978.

Warner RG \& Breuer JH Jr (1972) Nutrient requirements of the laboratory rat. In Nutrient Requirements of Laboratory Animals, pp. 56-93. Washington, DC: National Academy of Sciences.

Weber PC, Fischer S, von Schacky C, Lorenz R \& Strasser T (1986) Dietary omega-3 polyunsaturated fatty acids and eicosanoid formation in man. In Health Effects of Polyunsaturated Fatty Acids in Seafoods. Orlando, FL: Academic Press.

Widdowson EM (1981) The role of nutrition in mammalian reproduction. In Environmental Factors in Mammal Reproduction, pp. 143-159 [D Gilmore and B Cook, editors]. Baltimore: University Park Press.

Winship AJ, Trites AW \& Rosen DAS (2002) A bioenergetics model for estimating the food requirements of Steller sea lions (Eumetopias jubatus) in Alaska. Marine Ecology Progress Series 229, 291-312.

Yonekubo A, Honda S, Okano M, Takahashi K \& Yamamoto Y (1993) Dietary fish oil alters rat milk composition and liver and brain fatty acid composition of fetal and neonatal rats. Journal of Nutrition 123, 1703-1708.

Zhang Z, Benson B \& Logan JL (1992) Dietary fish oil delays puberty in female rats. Biology of Reproduction 47, 998-1003. 